\title{
Palaeoecological evidence for changes over the past 200 years in chironomid communities of a shallow lake exposed to cyanobacterial toxins
}

\author{
Anna Kaczorowska $\cdot$ Ryszard Kornijów
}

Received: 30 March 2012/ Accepted: 18 August 2012/Published online: 5 September 2012

(C) The Author(s) 2012. This article is published with open access at Springerlink.com

\begin{abstract}
In spite of the existence of a number of papers applying the biomarker approach using pigments or akinetes to discuss the impact of cyanobacteria on the functioning of lakes in the palaeoenvironmental context, their sedimentary imprint in the form of microcystins (MCs) has never been taken into consideration. Our objective was to reconstruct 200 years of the development of chironomid assemblages in a shallow Polish lake with notoriously blooming toxic cyanobacteria. A $50-\mathrm{cm}$ long sediment core sampled from the central part of the lake was sliced every $1 \mathrm{~cm}$, dated, and analysed for the subfossil remains of Chironomidae and concentrations of MCs. The fauna underwent four distinct stages in its recent history: three periods when the assemblages were typical of hypertrophic conditions (the first one comprising the entire nineteenth century, and the second and third one including approximately the last 30 years of the twentieth century), separated by a "eutrophic" assemblage during the first 70 years of the twentieth century. The typical features of the "eutrophic" midge
\end{abstract}

Handling Editor: Piet Spaak.

A. Kaczorowska

Department of Hydrobiology, University of Life Sciences in Lublin, Dobrzańskiego 37, 20-262 Lublin, Poland

R. Kornijów ( $\square)$

Department of Fisheries Oceanography and Marine Ecology, National Marine Fisheries Research Institute, Kołłątaja 1, 81-332 Gdynia, Poland

e-mail: ryszard.kornijow@mir.gdynia.pl assemblage were high total densities and high values of taxonomic richness and diversity. This period coincided with relatively low concentrations of MCs in the sediments. Sediments from the hypertrophic periods were distinguished by taxonomic impoverishment of chironomids, low Shannon diversity index, a strong decrease in chironomid numbers, and high concentrations of MCs. Significant negative correlations with MCs along the sediment profile were observed for eurytopic chironomids. MC concentrations were also negatively but not significantly correlated with total density of chironomids, their benthic and epiphytic assemblages, species richness, and diversity index.

Keywords Subfossil chironomids - Zoobenthos · Sediments $\cdot$ Cyanobacteria $\cdot$ Microcystins . Eutrophication

\section{Introduction}

During the last century, eutrophication in lakes accelerated significantly as a result of human impact, often leading to hypertrophy (Harper 1992). A noticeable symptom of excessive lake fertility is cyanobacterial blooms (e.g. Reynolds and Walsby 1975; Jensen et al. 1994; Anderson et al. 2002). The blooms result in far-reaching transformations in lakes' ecosystems, including deterioration of oxygen conditions, changes in the structure of bottom sediments, 
disappearance of submerged plants, and as a consequence profound alterations in the structure of other communities, including impoverishment of their species diversity (Scheffer 1998).

There are many papers that use a biomarker approach such as pigments or akinetes to trace cyanobacteria in sediment cores and discuss them in a palaeoenvironmental context (e.g. Hall et al. 1999; Francis 2001; Eilers et al. 2004; Waters et al. 2005; Routh et al. 2009).

The effect of cyanobacteria can be strengthened by microcystins (MCs), toxic metabolites that they secrete (Carmichael 1992; Anderson et al. 2002). Their effect on aquatic life, and particularly insects, is still little studied (Kotak et al. 1996; Chen and Xie 2008). MCs can cause acute effects (e.g. reduction in survivorship, feeding inhibition, paralysis), chronic effects (e.g. reduction in growth and fecundity), biochemical alterations, and changes in life cycle in aquatic invertebrates such as mussels and crustaceans (Ferrão-Filho and Kozlowsky-Suzuki 2011).

Traces of MCs are detectable not only in the superficial sediment layers, but also in the deeper sediments deposited in the past (Pawlik-Skowrońska et al. 2010). This permits analysis of the impact of cyanobacterials on aquatic communities in long-term history. The present paper is a first such attempt. The objective of the study is to reconstruct 200 years of development of chironomid assemblages in Lake Syczyńskie, a small and shallow lake with notoriously blooming toxic cyanobacteria, described by PawlikSkowrońska et al. (2010).

\section{Study area}

Lake Syczyńskie is located in the Łęczna-Włodawa Lakeland, within the Cretaceous elevation of the Chełm Hills (518170N and 238140E) (Fig. 1). It is small (surface area $5.71 \mathrm{ha}$ ) and shallow (maximum depth $2.9 \mathrm{~m}$ ) with two small inflows and one outflow. The lake's southern shore is adjacent to a carbonate peatland. The other part of the lake borders on the small village Syczyn. The lake's drainage basin is relatively large (458.2 ha) in relation to the lake's surface area. This results in the high value of the Ohle's index (80.2). This index (quotient of total drainage area and lake area) measures a potential magnitude of the pressure exerted by a drainage basin on a lake; the higher the value of a lake index, the

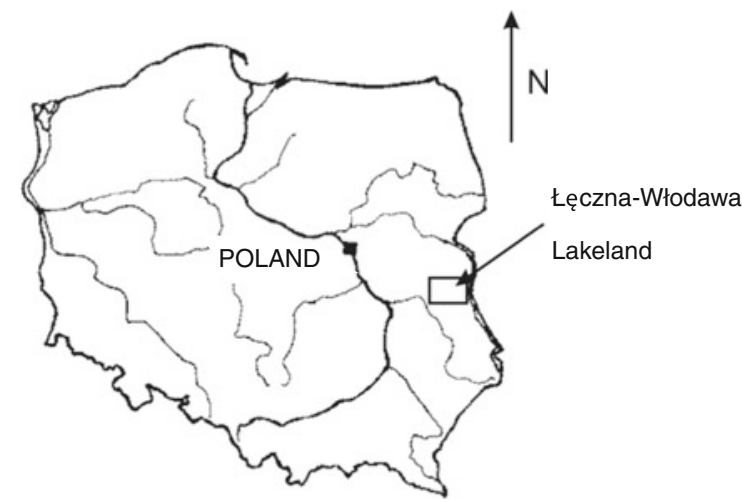

Fig. 1 Location of Łęczna-Włodawa Lakeland and Lake Syczyńskie

stronger the basin's effect on the lake (BajkiewiczGrabowska 2001).

Approximately $94 \%$ of the catchment is used for agriculture, concentrated mostly on fertile black earth soils and rendzinas (Smal et al. 2005). Annual external loading of $\mathrm{P}$ and $\mathrm{N}$ to the lake is very high. The loads of nitrogen and phosphorous are 28 and 10 times higher, respectively, than the dangerous level, according to Vollenweider's (1976) criteria (Smal et al. 2005). Chlorophyll- $a$ concentrations, water transparency, total phosphorus (TP), and electric conductivity (EC) are typical of hypertrophic, phytoplankton-dominated lakes (Table 1). The near-bottom waters are well oxygenated (Table 1), probably due to lake shallowness. This allows mixing of the water column by wind in the summer, and enables photosynthetic activity by benthic/sessile algae in year-round, including the winter. Consequently, even under ice cover, the oxygen saturation does not drop below $48 \%$ (Kornijów, unpubl.).

The lake is surrounded by a 5-30-m wide belt of emergent vegetation, mainly Phragmites australis (Cav.) Trin. ex Steud. Submerged plants barely exist, except for some stray shoots of Ceratophyllum demersum L. (Kornijów et al. 2002). The phytoplankton is totally dominated by cyanobacteria Plantothrix agardhii (Gom.) Anagn. and Kom.- the main producer of toxic MCs (Pawlik-Skowrońska et al. 2008).

\section{Materials and methods}

A 50-cm long sediment core was sampled in April 2005 from the central part of the lake by means of a 
Table 1 Physical-chemical characteristics of water of Lake Syczyńskie

\begin{tabular}{ll}
\hline $\mathrm{pH}^{\mathrm{a}}$ & 8.52 \\
$\mathrm{O}_{2}\left(\mathrm{mg} \mathrm{dm}^{-3}\right)^{\mathrm{b}}$ & $6.0-14.8$ \\
$\mathrm{Secchi} \mathrm{Disc}, \mathrm{SD}(\mathrm{m})^{\mathrm{a}}$ & 0.3 \\
$\mathrm{EC}\left(\mu \mathrm{sm}^{-1}\right)^{\mathrm{a}}$ & 514 \\
$\mathrm{TP}\left(\mathrm{mg} \mathrm{dm}^{-3}\right)^{\mathrm{a}}$ & 0.239 \\
$N_{\text {tot }}\left(\mathrm{mg} \mathrm{dm}^{-3}\right)^{\mathrm{a}}$ & 1.7 \\
$\mathrm{Chl}-a\left(\mu \mathrm{g} \mathrm{dm}^{-3}\right)^{\mathrm{c}}$ & $162-358$ \\
Concentrations of intracellular microcystins $(\mu \mathrm{g}$ & $50-90$ \\
$\quad$ equivalent MC-LR dcm & \\
TSI &
\end{tabular}

EC, electric conductivity; TP, total phosphorus; TSI, Carlson's Trophic State Index determined on the basis of Chl- $a$; SD and TP, following Kornijów et al. (2002)

a Mean values for the period May-October 2001, following Smal et al. (2005)

b Values from the monthly monitoring programme in 2005-2009 (Kornijów, unpublished)

c Following Kornijów et al. (2002)

d Following Pawlik-Skowrońska et al. (2010)

Table 2 Results of the Pearson correlation between concentrations of microcystins in bottom sediments and total numbers of chironomids, numbers of their ecological assemblages, and most abundant taxa

\begin{tabular}{lrll}
\hline Variable & $r$ & $p$ & $n$ \\
\hline Total Chironomidae & -0.3227 & NS & 22 \\
Tanypodinae & 0.1560 & NS & 22 \\
Tanytarsini & -0.2934 & NS & 22 \\
Benthic Chironomidae & -0.3423 & NS & 22 \\
Epiphytic Chironomidae & -0.1858 & NS & 22 \\
Eurytopic Chironomidae & -0.4915 & $*$ & 21 \\
Chironomus sp. & -0.4436 & $*$ & 21 \\
Glyptotendipes sp. & 0.1329 & NS & 21 \\
Endochironomus sp. & -0.2915 & NS & 22 \\
Dicrotendipes sp. & -0.4337 & NS & 22 \\
Cricotopus sp. & -0.1617 & NS & 22 \\
Total richness & -0.3516 & NS & 22 \\
Shannon index & -0.2285 & NS & 22 \\
\hline
\end{tabular}

$* p<0.05$

60-mm diameter UWITEC sampler pushed to the sediments using a 6-m long rod. The core was sliced to $1 \mathrm{~cm}$ layers using a sediment slicer (Kornijów 2009), placed in bags, and stored at $4{ }^{\circ} \mathrm{C}$ until analyses could be carried out. Up to a depth of $20 \mathrm{~cm}$, the sediment was analysed at a resolution of $1 \mathrm{~cm}$, and deeper every $5 \mathrm{~cm}$. In total, 26 sediment layers were studied. The general laboratory procedure for chironomid analysis followed that described by Hofman (1986), with minor modifications. Subsamples of wet sediment were deflocculated with $8 \% \mathrm{KOH}$ at a temperature of $30-32{ }^{\circ} \mathrm{C}$ for 3 days. Then, the material was sieved through $180 \mu \mathrm{m}$ mesh, and dehydrated with three successive treatments of ethanol $(75,90$, and $99 \%)$. Individual head capsules were picked with forceps from a Bogorov counting chamber under $40 \times$ magnification using a stereomicroscope. Individuals were identified to the lowest possible taxonomic level, according to Wiederholm (1983), Walker (2000) and Brooks et al. (2007). Two half head capsules of the same taxon were counted as one complete head capsule. A minimum of 50 head capsules (HC) was extracted from each sediment sample (Heiri and Lotter 2001; Quinlan and Smol 2001) except for the following sediment sections: $5 \mathrm{~cm}(\mathrm{HC}=30), 7 \mathrm{~cm}$ $(\mathrm{HC}=38), 9 \mathrm{~cm} \quad(\mathrm{HC}=33), 10 \mathrm{~cm} \quad(\mathrm{HC}=0)$, $11 \mathrm{~cm} \quad(\mathrm{HC}=10), \quad 12 \mathrm{~cm} \quad(\mathrm{HC}=33), \quad 40 \mathrm{~cm}$ $(\mathrm{HC}=32)$, and $45 \mathrm{~cm}(\mathrm{HC}=48)$. The midge larvae encountered were divided into three ecological assemblages: epiphytic, benthic, and eurytopic, depending on their substrate preferences (Tarkowska-Kukuryk and Kornijów 2008; Tarkowska-Kukuryk 2011). Tanytarsini was distinguished as a separate group due to the difficulties in the identification of their remains to the genera level.

Data were compiled and a chironomid percentage diagram was produced by means of Tilia 2.0 version (Grimm 1993). Cluster analysis (Grimm 1987) using Orloci's chord distance was applied to identify groups of samples with similar chironomid assemblages, and to divide them into local chironomid assemblage zones (LCAZ). The chord distance was chosen as distance coefficient given many zero entries in the chironomid subfossil matrix (Legendre and Legendre 1998).

We applied the Shannon-Wiener index $H^{\prime}$ ) to describe chironomid diversity:

$H^{\prime}=-\sum_{i=1}^{S} p_{i} \ln p_{i}$

where $S$-number of species per sample; $p_{i}$-relative abundance of $i$ th taxon; $=n_{i} / N, N$-total number of all 
individuals; $n_{i}$-number of individuals of $i$ th taxon; $\ln -\log$ to base 2 .

Pearson's correlation coefficients were calculated to identify significant associations between densities of midge taxa and concentrations of MCs. Before calculations, outliers in both data sets were identified and rejected by means of the Dixon's $Q$ test (Dean and Dixon 1951).

The age of the sediment layers, calculated based on a constant rate of supply of unsupported ${ }^{210} \mathrm{~Pb}$ model, and mean sedimentation rate during the last 150 years (3.4 $\mathrm{mm} \mathrm{year}^{-1}$ ) are discussed by Gạsiorowski (2008). Samples for concentrations of microcystins were collected in the same time, place, and manner as those for chironomids. The total MC concentration was analyzed and determined by gas chromatography/ mass spectrometry (Pawlik-Skowrońska et al. 2010). The method is based on oxidation of Adda (specific aminoacid present in all iso forms of MCs together with degraded ones) to 2-methyl-3-methoxy-4-phenylbutyric acid (MMPB) and determination of MMPB as methyl ester. The MC concentrations were expressed as $\mu \mathrm{g}$ equivalent MC-LR $\mathrm{g}^{-1}$ dry weight (DW) of sediment, where L and R are the symbols of amino acids that are incorporated in MCs.

\section{Results}

Changes in chironomid assemblages in a sediment profile

A total of 807 chironomid head capsules belonging to 17 taxa were found in 26 sediment samples retrieved from the core (Fig. 2). The material analysed was dominated by epiphytic forms constituting $58.5 \%$ of total numbers. Benthic forms were less abundant, amounting to $16 \%$ of the total. Eurytopic taxa constituted $10 \%$. Tanytarsini and undetermined Chironomidae constituted 12 and $3.5 \%$, respectively.

Based on the analysis of similarities in percentage contributions of fossil chironomids contained in the entire sediment core, four local chironomid assemblage zones (LCAZ) were distinguished (Fig. 2). The oldest sediments analyzed (LCAZ-I, 50-30 cm) contained very changeable abundance of $\mathrm{HC}$, achieving maxima at $50 \mathrm{~cm}$ and $35 \mathrm{~cm}$ (Fig. 2). The fauna was constituted mostly of littoral epiphytic taxa, with Cricotopus sp. and Glyptotendipes sp. as dominants.
The benthic assemblage made insignificant contributions and was dominated by pelophilous benthic Chironomus sp., most numerous at $40 \mathrm{~cm}$ depth. Eurytopic larvae and Tanytarsini were rare, being most abundant in the bottom part of the zone. The period was distinguished by relatively low species richness and diversity. The MC concentrations were quite high, especially at 40 and $35 \mathrm{~cm}$ depth (Fig. 2).

The LCAZ-II $(25-12 \mathrm{~cm})$ showed the highest concentrations of HC. They dropped at about $11 \mathrm{~cm}$, corresponding to the year $\sim 1975$. The relative abundance of benthic and eurytopic taxa increased, whilst that of epiphytic forms decreased (Fig. 2). Epiphytic chironomids were still dominated by Cricotopus sp. and Glyptotendipes sp., benthic chironomids were dominated by Chironomus sp., and Dicrotendipes sp. was most abundant amongst eurytopic chironomids. Tanytarsini reached their highest relative numbers in this zone. Several other genera also occur for the first time here: Ablabesmyia, Procladius, Polypedilum, Microtendipes, Limnophyes, Cladopelma, and Propsilocerus. Consequently, the total species richness and species diversity were the highest in the whole sediment profile, but tended to decrease in the top section of this zone. The MC concentrations in the sediment record were lowest in zone LCAZ-II, and, except for one peak at $17 \mathrm{~cm}$, they did not fluctuate significantly (Fig. 2).

The beginning of LCAZ-III $(11-7 \mathrm{~cm})$ involved a rapid decrease in the concentrations of subfossil chironomids until their total disappearance at the level of $10 \mathrm{~cm}$. The highest numbers were reached by pelophilous Chironomus sp. Another benthic chironomid, Propsilocerus lacustris Kieff., increased slightly, as did Procladius sp. Amongst epiphytic chironomids, the highest contribution was that of Cricotopus sp., followed by Endochironomus sp. The remaining taxa in this zone occurred sporadically, and Psectrocladius sp. disappeared. In the uppermost layer of the zone, Tanytarsini appeared again (Fig. 2). The total richness and diversity index were close to zero in the bottom part but increased starting from $9 \mathrm{~cm}$. MCs tripled their concentrations, being highest between 11 and $9 \mathrm{~cm}$.

The zone represented by the youngest sediments, LCAZ-IV $(6-0 \mathrm{~cm})$, was distinguished by the growing numbers of head capsules, and relatively constant values of both species richness and diversity, with minima in the intermediate sequence (Fig. 2). Benthic 
Fig. 2 Relative abundance of chironomid taxa, their assemblages, total richness, total numbers of head capsules, diversity index $\left(H^{\prime}\right)$, and concentrations of microcystins

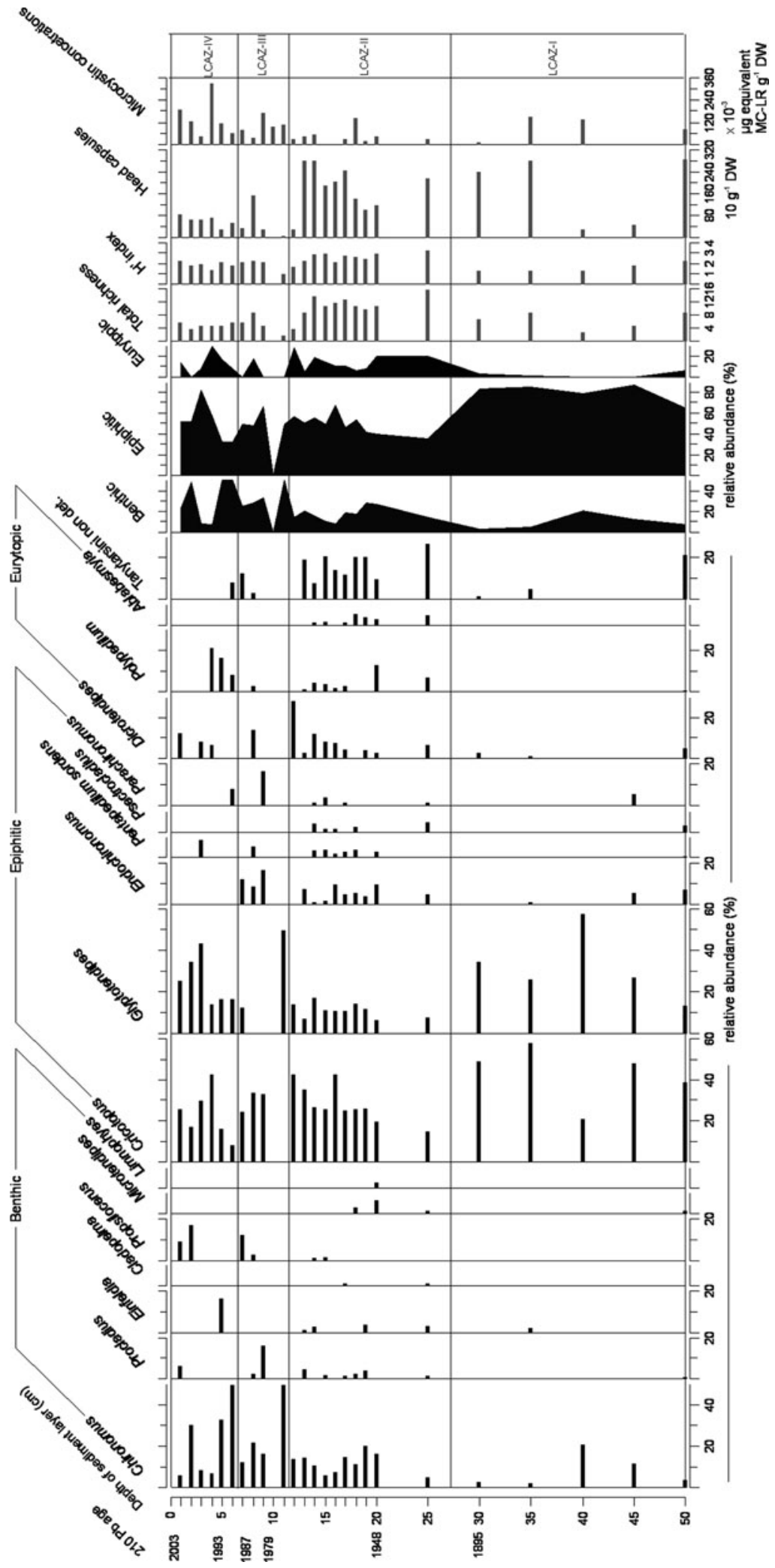


larvae were dominated by Chironomus sp., but some other benthic taxa appeared again-Einfeldia sp. at $5 \mathrm{~cm}$ depth and $P$. lacustris at 2 and $3 \mathrm{~cm}$. In the epiphytic assemblage, Cricotopus sp. and Glyptoptendipes sp. prevailed. Endochironomus sp., abundant in lower zones, disappeared completely. Tanytarsini occurred only at the bottom of the zone. The concentrations of MCs increased markedly, and reached the highest recorded value exceeding $0.300 \mu$ g equivalent to MC-LR g ${ }^{-1}$ DW (Fig. 2).

Response of chironomids to MC concentrations

The correlations between the concentrations of MCs and the abundance of chironomid ecological assemblages were negative, but significant $(r=-0.4915)$ only in the case of eurytopic assemblage (Table 2). The total head capsule concentrations, chironomid species richness and diversity correlated negatively with MCs as well $(r=-0.3516, r=-0.3227$ and $r=-0.2285$, respectively), but none of these correlations were significant.

The most abundant taxa correlated negatively with MCs, but significant relationships were found only for Chironomus sp. larvae $(r=-0.4436)$. There were only two taxa, Glyptotendipes sp. and Tanypodinae, that showed positive, but very weak and statistically insignificant, correlations with MCs (Table 2).

\section{Discussion}

This study reveals that the lowest productivity and MC concentrations in the lake's recent history occurred in the first 70 years of the twentieth century (LCAZ-II). This coincides with the highest concentrations of head capsules in the material, and higher taxonomic richness and diversity compared with other zones. The lake's productivity suggests a eutrophic character in this period. Cyanobacterial blooms were not intensive, as evidenced by the consistently low values of MC concentrations in LCAZ-II. In the late 1960s, numerous patches of $C$. demersum L. and Potamogeton natans L. were still found in the lake (Kowalczyk 1979), suggesting relatively good light conditions that allowed the development of elodeids. This is reflected in the fossil chironomid material by high species richness of epiphytic forms and large contributions of Tanytarsini.
The sediments from the earlier period, including the nineteenth century (zone LCAZ-I), and the later two periods, comprising about 25 last years of the twentieth century (LCAZ-III and LCAZ-IV), are distinguished by taxonomic impoverishment of chironomids, low values of the species richness and diversity index, and a strong decrease in the total chironomid numbers. These coincided with MC concentrations up to five times higher than in LCAZII, suggesting intensive cyanobacterial blooms and hypertrophic conditions. The poor ecological state of the lake is confirmed by the low numbers of Tanytarsini. They are recognized as inhabitants of weakly eutrophicated waters (Saether 1979), which is related to their small individual size and reduced efficacy of haemoglobin (Bryce and Hobart 1972).

We do not have enough information to specify the exact causes for the hypertrophication of the lake in the nineteenth century. It can be assumed that it was related to the proximity of the village and agriculture, as determined repeatedly in various studies (e.g. Bechmann et al. 2005; Smal et al. 2005). The high ratio of catchment area to lake area could have reinforced the high nutrient loading and hastened the lake's degradation (Harper 1992).

Another deterioration of the environmental conditions (LCAZ-III), indicated by changes in chironomid fauna and elevated concentrations of MC commenced at the beginning of the 1980s. The reason for the degradation of the ecosystem was probably longlasting (1972-1997) dumping of manure into the lake from the nearby cattle and hog farm, a fact corroborated by the testimony of the local residents. The high contribution of typical epiphytic midges, such as Glyptotendipes sp. and Cricotopus sp. in this period, suggests luxuriant development of vegetation, at least emergent vegetation in the form of expanding Phragmites belt. Nowadays, both Glyptotendipes and Cricotopus are important components of the epiphytic fauna inhabiting reed stems in Lake Syczyńskie (Halkiewicz 2005; Tarkowska-Kukuryk 2011). This is in agreement with the opinion, considering these chironomid genera as typical indicators of highly eutrophicated lakes (Brodersen et al. 2001; Brodersen and Quinlan 2006). According to some authors (Ali 1990; Frouz et al. 2004), Glyptotendipes larvae can utilize cyanobacteria as a source of food. This might explain the weak correlation between concentrations of the midge and MCs (Table 2). 
High accumulation of organic matter derived from manure in the 1980s could enhance oxygen demand in the bottom sediments, which are fine detritus gyttja. However, the sediments were pinkish in the top ca. $0.5 \mathrm{~cm}$ depth, and beige brown below this depth. This seems to exclude anoxic conditions, but not hypoxia, at least at the water sediment interface. Although many invertebrates, including chironomids, have physiological and behavioural adaptations to cope with oxygen shortages (Kornijów and Moss 2002; Brodersen and Quinlan 2006, and the references therein), the hypoxic conditions must have eliminated some chironomids living in the deeper parts of the lake, except for those resistant to oxygen deficits (Chironomus and Procladius). Another chironomid, $P$. lacustris, tolerant of high nutrient levels (Kornijów and Halkiewicz 2007) even increased its density (Fig. 2).

Manure has not been dumped in the lake since 1997, but the nutrient load accumulated in the sediment can be a significant source of the so-called internal eutrophication (Scheffer 1998; Kowalczewska-Madura et al. 2010). In addition, agricultural activity in the catchment and poor sewage management (Smal et al. 2005; Dawidek et al. 2009) are currently important factors determining the quality and productivity of the lake. This results in year-round cyanobacterial blooms and high production of MCs (Pawlik-Skowrońska et al. 2008). However, the chironomid fauna shows some signs of revival, manifested by the increase in HC concentrations, and the stable species richness and diversity values (Fig. 2, zone LCAZ-IV).

So far, MC toxicity, specifically to insects, including chironomids, has received limited attention (Ferrão-Filho and Kozlowsky-Suzuki 2011). No studies regarding the issue have been carried out in the scope of paleolimnology, although there are several papers that use pigments to trace cyanobacteria in sediment cores to reconstruct lake history (e.g. Waters et al. 2005; Routh et al. 2009).

In Lake Syczyńskie, particularly in winter, decaying cells of Planktothrix agardii cover the sediments and release high amounts of MCs throughout the year. The toxins are extremely stable due to their chemical structure (Pawlik-Skowrońska et al. 2008). It is very likely that their long persistence in the water may hamper the development of populations of benthic midge larvae. The negative correlation between MCs and several chironomid taxa (Table 2) supports this supposition. The majority of the correlations obtained were not significant, but one should consider that information derived from each sediment layer is of cumulative character.

The structuring role of cyanobacterial blooms towards chironomid populations may result not only from the harmful effect of the toxins, but also from alterations in the habitat conditions caused by cells densely packed in the scum. Scum was often reported to dramatically worsen water oxygenation (discussed above), light climate, and $\mathrm{pH}$ values (e.g. Zohary 1985; Scheffer 1998).

The approach we present here broadens the possibility of tracking the changes in palaeoenvironment, suggesting the functional linkages between the symptoms of lake hypertrophication in the form of MCs production by cyanophytes and the development of other biotic components, such as chironomids, as an example.

Acknowledgements The study was supported by the State Committee for Scientific Research, project No. P06S00127. We express our thanks to David Strayer and Małgosia Kornijów for their help in the English language.

Open Access This article is distributed under the terms of the Creative Commons Attribution License which permits any use, distribution, and reproduction in any medium, provided the original author(s) and the source are credited.

\section{References}

Anderson DM, Glibert PM, Burkholder JM (2002) Harmful algal blooms and eutrophication: nutrient sources, composition, and consequences. Estuaries 25:704-726

Ali A (1990) Seasonal changes of larval food and feeding of Chironomus crassicaudatus (Diptera: Chironomidae) in a subtropical lake. J Am Mosq Control Assoc 6:84-88

Bajkiewicz-Grabowska E (2001) Lake geoecosystem as an indicator of the rate of natural eutrophication of water reservoirs. Limnol Rev 8:9-12

Bechmann ME, Berge D, Eggestad HO, Vandsemb SM (2005) Phosphorus transfer from agricultural areas and its impact on the eutrophication of lakes - two long term studies from Norway. J Hydrol 304:238-250

Brodersen KP, Odgaard BV, Vestergaard O, Anderson NJ (2001) Chironomid stratigraphy in shallow and eutrophic Lake Sobygaard, Denmark: chironomid-macrophyte cooccurrence. Freshw Biol 46:253-267

Brodersen KP, Quinlan R (2006) Midges as palaeoindicators of lake productivity, eutrophication and hypolimnetic oxygen. Quat Sci Rev 25:1995-2012 
Brooks SJ, Langdon PG, Heiri O (2007) The identification and use of Palaearctic Chironomidae larvae in palaeoecology. QRA Technical Guide No. 10. Quaternary Research Association, London

Bryce D, Hobart A (1972) The biology and identification of the larvae of the Chironomidae (Diptera). Entomol Gaz 23:175-217

Carmichael WW (1992) Cyanobacteria secondary metabolites-the MCs. J Appl Bacteriol 72:460-466

Chen J, Xie P (2008) Accumulation of hepatotoxic MCs in freshwater mussels, aquatic insect larvae and oligochaetes in a large, shallow eutrophic lake (Lake Chaohu) of subtropical China. Fresen Environ Bull 17:849-854

Dawidek J, Pęczuła W, Ferencz B (2009) The role of catchment and in-lake processes in shaping trophic conditions of the shallow lake Syczyńskie (Eastern Poland). Ecohydrol Hydrobiol 9:193-200

Dean RB, Dixon WJ (1951) Simplified statistics for small numbers of observations. Ann Chem 23:636-638

Eilers JM, Kann J, Cornett J, Moser K, St. Amand A (2004) Paleolimnological evidence of change in a shallow, hypereutrophic lake: Upper Klamath Lake. Hydrobiologia 520:7-18

Ferrão-Filho AS, Kozlowsky-Suzuki B (2011) MCs: bioaccumulation and effects on aquatic animals. Mar Drugs 9:2729-2772

Francis DR (2001) A record of hypolimnetic oxygen conditions in a temperate multi-depression lake from chemical and chironomid remains. J Paleolimnol 25:351-365

Frouz J, Ali A, Lobinske RJ (2004) Laboratory evaluation of six algal species for larval nutritional suitability of the pestiferous midge Glyptotendipes paripes (Diptera: Chironomidae). J Econ Entomol 97:1884-1890

Gąsiorowski M (2008) Deposition rate of lake sediments under different alternative stable states. Geochronometria 32:29-35

Grimm EC (1987) CONISS: A fortran 77 program for stratigraphically constrained cluster analysis by the method of incremental sum of squares. Comput Geosci 13:13-35

Grimm EC (1993) Tilia 2.0 (computer software). Illinois State Museum, Research and Collections Center, Springfield, II

Halkiewicz A (2005) Subfossil remains of Chironomidae from two shallow lakes representing extreme alternative states. Stud Quat 22:45-49

Hall RI, Leavitt PR, Dixit AS, Quinlan R, Smol JP (1999) Effects of agriculture, urbanization and climate on water quality in the northern Great Plains. Limnol Oceanogr 44:739-756

Harper DM (1992) Eutrophication of freshwaters: principles, problems and restoration. Chapman and Hall, London

Heiri O, Lotter AF (2001) Effect of low count sums on quantitative environmental reconstructions: an example using subfossil chironomids. J Paleolimnol 26:343-350

Hofman W (1986) Chironomid analysis. In: Berglund BE (ed) Handbook of holocene palaeohydrology. John Wiley, Chichester, pp 715-727

Jensen JP, Jeppesen E, Olrik K, Kristensen P (1994) Impact of nutrients and physical factors on the shift from cyanobacterial to chlorophyte dominance in shallow Danish lakes. Can J Fish Aquat Sci 51:1692-1699
Kornijów R (2009) Nasadka tnąca. Nr patentu: 383855 [Sectioning device. Patent no. A1 8383855]. J Pat Office Pol 11:21 (in Polish)

Kornijów R, Moss B (2002) Do night oxygen depletions contribute to the summer decline in abundance of zoobenthos in lake littoral? Verh Intern Ver Limnol 28:1899-1901

Kornijów R, Pęczuła W, Lorens B, Ligęza S, Rechulicz J, Kowalczyk-Pecka D (2002) Shallow Polesie lakes from the view point of alternative stable states theory. Acta Agrophys 68:61-72

Kornijów R, Halkiewicz A (2007) Are the larvae of Propsilocerus lacustris Kieffer 1923 (Diptera, Chironomidae) favoured by nutrient-rich lakes? Aquat Insect 29:187-194

Kotak BG, Zurawell R, Prepas E, Holmes CF (1996) MCs-LR concentration in aquatic food web compartments from lakes of varying trophic status. Can J Fish Aquat Sci 53:1974-1985

Kowalczewska-Madura K, Dondajewska R, Gołdyn R (2010) Internal phosphorus loading in selected lakes of the Cybina River valley. Oceanol Hydrobiol Stud 39:35-45

Kowalczyk C (1979) Fauna skorupiaków jezior Pojezierza Łęczyńsko-Włodawskiego na tle warunków limnologicznych. cz. III. Jeziora o IV stopniu degradacji [Crustacean fauna of the lakes of the Łęczna-Włodawa Lakeland in relation to limnological conditions. Part III. Lakes with the IVth degree of degradation]. Ann Univ MCS sec C 34:261-278 (in Polish)

Legendre P, Legendre L (1998) Numerical ecology, 2nd English edn. Elsevier Science B.V., Amsterdam

Pawlik-Skowrońska B, Pirszel J, Kornijów R (2008) Spatial and temporal variation in MCs concentrations during perennial bloom of Planktothrix agardhii in a hypertrophic lake. Ann Limnol Int J Lim 44:63-68

Pawlik-Skowrońska B, Kornijów R, Pirszel J (2010) Sedimentary imprint of cyanobacterial blooms-a new tool for insight into recent history of lakes. Pol J Ecol 58:663-670

Reynolds CS, Walsby AE (1975) Water blooms. Biol Rev $50: 437-481$

Routh J, Choudhary P, Meyers PA, Kumar B (2009) A sediment record of recent nutrient loading and trophic state change in Lake Norrviken, Sweden. J Paleolimnol 42:325-341

Quinlan R, Smol JP (2001) Setting minimum head capsule abundance and taxa deletion criteria in chironomid-based inference models. J Paleolimnol 26:327-342

Saether OA (1979) Chironomid communities as water quality indicators. Holarctic Ecol 2:65-74

Scheffer M (1998) Ecology of shallow lakes. Chapman and Hall, London

Smal H, Kornijów R, Ligęza S (2005) The effect of catchment on water quality and eutrophication risk of five shallow lakes (Polesie region, Eastern Poland). Pol J Ecol 53:313-327

Tarkowska-Kukuryk M, Kornijów R (2008) Influence of spatial distribution of submerged macrophytes on Chironomidae assemblages in shallow lakes. Pol J Ecol 56:747-758

Tarkowska-Kukuryk M (2011) Distribution and composition of epiphytic midges (Diptera: Chironomidae) in relation to emergent macrophytes cover in shallow lakes. Pol J Ecol 59:141-151 
Vollenweider RA (1976) Advances in defining critical loading level for phosphorus in lake eutrophication. Mem Ist Ital Idrobiol 33:53-85

Walker IR (2000) The WWW field guide to subfossil midges. http://www.ouc.bc.ca/eesc/iwalker/wwwguide/

Waters MN, Schelske CL, Kenney WF, Chapman AD (2005) The use of sedimentary algal pigments to infer historic algal communities in Lake Apopka, Florida. J Paleolimnol 33:53-71
Wiederholm T (ed) (1983) Chironomidae of the Holarctic region: keys and diagnoses. Part 1. Larvae. Entomol Scand Suppl 19:1-457

Zohary T (1985) Hyperscum of the cyanobacterium Microcystis aeruginosa in a hypertrophic lake (Hartbeespoort Dam, South Africa). J Plankton Res 7:399-409 